ISSN : ISSN 2442-4986

An-Nadaa: Jurnal Kesehatan Masyarakat, 8 (1) Juni 2021 :26-33

https://ojs.uniska-bjm.ac.id/index.php/ANN/article/view/4390

\title{
PENGARUH ANTARA PENDIDIKAN, PEKERJAAN, DAN PENGETAHUAN MENGENAI COVID-19 TERHADAP KEPATUHAN PENERAPAN PSBB DENGAN MENGGUNAKAN METODE PATH ANALYSIS DI WILAYAH JABODETABEK
}

\author{
THE INFLUENCE OF EDUCATION, WORKS, AND KNOWLEDGE OF COVID-19 ON \\ COMPLIANCE WITH THE IMPLEMENTATION OF PSBB BY USING PATH \\ ANALYSIS METHOD IN JABODETABEK AREAS
}

\author{
Ekadipta ${ }^{1 *}$, Febri Hidayat ${ }^{2}$, Dede Komarudin ${ }^{3}$, Priyonggo Artaji ${ }^{4}$, Isngunaenah ${ }^{5}$, Mita \\ Sukamdiyah ${ }^{6}$ \\ 1,2,3 Fakultas Sains dan Teknologi, Institut Sains dan Teknologi Al-Kamal, \\ Jl. Raya Al-Kamal No.2 Kedoya Selatan Jakarta, Indonesia \\ ${ }^{4}$ Apotek Icon Sehat, Jl. Perintis Kemerdekaan Kav. 99, Pulo Gadung, Jakarta Timur, \\ Indonesia \\ ${ }^{5}$ Apotek Mitra Medika, Jl. Boulevard Raya Blok FX 1 No.17, Kelapa Gading, Jakarta Utara, \\ Indonesia \\ ${ }^{6}$ Rumah Sakit Selaras, Jl. Raya Lapan Rumpin Cisauk, Tangerang, Indonesia \\ *Email: ekadipta@gmail.com
}

\begin{abstract}
Large-Scale Social Restrictions (PSBB) are applied so that residents, especially those in the red zone, limit their activities, especially outside the city to prevent further spread of COVID-19 in other areas (green zone). This study aims to determine whether there is a direct or indirect effect between education and work through knowledge of COVID-19 on compliance with the implementation of the PSBB in the JaBoDeTaBek area. The method in this study used a survey method with a quantitative approach and the research instrument used was a questionnaire. The sampling technique used is cluster random sampling which aims to divide the sample into the JaBoDeTaBek areas. The population in this study were 27,957,194 people who live in the JaBoDeTaBek area with a sample size of 400 respondents. This study uses multivariate analysis with two equation path analysis models to determine direct and indirect effects. The results obtained were that education had a significant indirect effect through knowledge of COVID-19 on compliance with the implementation of PSBB (0.094). Meanwhile work has a significant indirect effect through knowledge of COVID-19 on compliance with the implementation of PSBB (-0.009). Meanwhile, knowledge of COVID-19 has a direct effect of 0.566 on compliance with PSBB implementation.
\end{abstract}

Keywords: PSBB; Compliance; Education; Knowledge; Works

\begin{abstract}
ABSTRAK
Pembatasan Sosial Berskala Besar (PSBB) diterapkan agar warga khususnya yang berada di zona merah membatasi aktivitasnya, terlebih lagi ke luar kota untuk mencegah penyebaran COVID-19 lebih lanjut di wilayah lain (zona hijau). Penelitian ini bertujuan apakah terdapat pengaruh baik langsung maupun tidak langsung antara pendidikan dan pekerjaan melalui pengetahuan mengenai COVID-19 terhadap kepatuhan pelaksanaan penerapan PSBB di wilayah JaBoDeTaBek. Metode dalam penelitian ini menggunakan metode survei dengan pendekatan kuantitatif dan instrument penelitian yang digunakan adalah kuisioner. Teknik sampling yang digunakan adalah cluster random sampling yang bertujuan untuk membagi sampel kedalam wilayah JaBoDeTaBek. Populasi dalam penelitian ini adalah masyarakat yang berdomisili di wilayah JaBoDeTaBek sebanyak 27.957.194 jiwa dengan jumlah sampel yang diambil sebesar 400 responden. Penelitian ini menggunakan analisis multivariate dengan metoda two equation path analysis model untuk mengetahui pengaruh langsung dan tidak langsung. Hasil yang didapat adalah pendidikan memiliki pengaruh signifikan secara tidak langsung melalui pengetahuan mengenai COVID-19 terhadap kepatuhan penerapan PSBB $(0,094)$. Sementara pekerjaan memiliki pengaruh signifikan secara tidak langsung melalui pengetahuan mengenai COVID-19 terhadap kepatuhan penerapan PSBB $(-0,009)$. Sedangakan, pengetahuan mengenai COVID-19 mempunyai pengaruh langsung sebesar 0,566 terhadap kepatuhan penerapan PSBB.
\end{abstract}

Kata Kunci: PSBB; Kepatuhan; Pendidikan; Pengetahuan; Pekerjaan 


\section{PENDAHULUAN}

Hasil penyelidikan awal diyakini bahwa COVID-19 ditularkan dari hewan ke manusia namun pada kasus selanjutnya ditemukan bahwa COVID-19 dapat ditularkan dari manusia ke manusia (1). Penularan COVID-19 pada manusia dapat menyebabkan terjadinya infeksi saluran pernafasan mulai dari flu biasa sampai penyakit yang lebih parah seperti Sindrom Pernapasan Timur Tengah (MERS) dan Sindrom Pernapasan Akut Parah (SARS) (2). Sebagian besar orang yang terinfeksi virus COVID-19 akan mengalami penyakit pernapasan ringan hingga sedang dan sembuh tanpa memerlukan perawatan khusus (3). Namun, orang yang lebih tua, dan mereka yang memiliki masalah medis mendasar seperti penyakit kardiovaskular, diabetes, penyakit pernapasan kronis, dan kanker lebih mungkin mengembangkan penyakit serius (4). Berdasarkan bukti ilmiah, COVID-19 dapat menular dari manusia ke manusia melalui percikan batuk/bersin (droplet), tidak melalui udara (5).

Terdapat sebanyak 663.740 kasus virus COVID-19 di dunia, dimana sebanyak 490.678 kasus dinyatakan positif terinfeksi dan telah menyebabkan kematian 30.879 jiwa di seluruh dunia (6). Sementara tingkat penyebaran COVID-19 di Indonesia terjadi begitu cepat dimana dalam jangka waktu 3 bulan sejak tanggal 28 Maret 2020 hingga 17 Mei 2020 telah bertambah sebanyak 16.359 orang di seluruh Indonesia yang positif terinfeksi COVID-19. Bila melihat perkembangan penyebaran COVID-19 dapat dilihat bahwa DKI Jakarta serta daerah provinsi di pulau jawa memiliki jumlah penyebaran tertinggi, dimana DKI Jakarta berada di urutan pertama yaitu dari 627 kasus pada 28 maret 2020 menjadi 2.670 pada 17 april 2020 dan pada akhirnya menembus 6.010 kasus warga positif terinfeksi Virus COVID-19 pada 17 mei 2020 (7). Cepatnya penyebaran COVID19 di Indonesia dan khususnya pada provinsi DKI Jakarta dikarenakan banyak warga menghiraukan himbauan pemerintah untuk tetap dirumah saja (8).

Guna menekan penyebaran COVID-19, Pemerintah Daerah JaBoDeTaBek (Jakarta, Bogor, Depok, Tangerang dan Bekasi) memberlakukan Pembatasan Sosial Skala Besar (PSBB) (9). PSBB diterapkan agar warga khususnya yang berada di zona merah membatasi aktivitasnya, terlebih lagi ke luar kota untuk mencegah penyebaran COVID-19 lebih lanjut di wilayah lain (zona hijau) (10). Diharapkan dengan diterapkannya PSBB masyarakat semakin patuh dan waspada, karena dengan adanya PSBB Polisi dapat menindak dengan tegas warga yang melanggar kebijakan PSBB (11).

Kenyataan di lapangan semenjak diberlakukan penerapan PSBB justru banyak warga melakukan pelanggaran protocol kesehatan. Berdasarkan pengamatan langsung serta pemberitan di media massa sebagaian besar pelanggar terjadi akibat warga kurang memahami bagaimana gejala, cara penularan, serta bagaimana mencegah penularan COVID-19. Hal ini dapat dilihat pada pemberitaan pada Kompas.com dimana 15 warga Sidoarjo terjangkit COVID-19 akibat dengan sengaja membuka peti serta pembungkus jenasah pasien positif terinfeksi COVID-19 (12). Berdasarkan penjelasan tersebut maka dilakukan penelitian yang bertujuan apakah terdapat pengaruh baik langsung maupun tidak langsung antara pendidikan dan pekerjaan melalui pengetahuan terhadap kepatuhan pelaksanaan penerapan PSBB di wilayah JaBoDeTaBek.

\section{BAHAN DAN METODE}

Metode dalam penelitian ini menggunakan metode survei dengan pendekatan kuantitatif. Instrument penelitian yang digunakan yaitu kuisioner dengan skala linkert (13). Penyebaran kuisioner dilakukan melalui aplikasi pesan (Whaatsup, Telegram, dan Linkedn), media sosial (Facebook dan Instagram), maupun membagikan secara manual. Kemudian dilakukan pengujian validitas dengan menggunakan pearson product moment, sedangkan untuk uji reliabilitas menggunakan teknik Alpha Cornbach yang dihitung menggunakan SPSS 21 (14). Teknik pengambilan sampel yang digunakan pada penelitian ini adalah cluster sampling yang bertujuan untuk membagi sampel kedalam wilayah JaBoDeTaBek kemudian dilanjutkan dengan pengembilan secara random (15).

Populasi dalam penelitian ini adalah jumlah masyarakat yang berdomsili di wilayah JaBoDeTaBek 27.957.194 orang (16). Sedangkan penentuan ukuran sampel pada penelitian ini meggunakan rumus Slovin dan didapat $\mathrm{N}=400$ orang responden yang tersebar di wilayah JaBoDeTaBek (17). Kriteria 
inklusi pada penelitian ini adalah masyarakat yang tinggal di wilayah JaBoDeTaBek, berusia minimal 16 tahun, dan bersedia mengisi kusioer. Penelitian ini menggunakan analisis multivariate dengan metoda two equation path analysis model untuk mengetahui pengaruh langsung dan tidak langsung (18). Sedangkan pengujian dilakukan dengan mencari koefisien determinan $\left(\mathrm{R}^{2}\right)$, uji $\mathrm{F}$, dan analisis regresi menggunakan SPSS 21 untuk melihat linieritas variabel pendidikan dan pekerjaan melalui pengetahun terhadap kepatuhan (19).

Tabel 1. Pembagian Jumlah Sampel

\begin{tabular}{lccc}
\hline Wilayah & Jumlah Penduduk & $\%$ & $\mathbf{n}$ \\
\hline DkI & & & \\
Jakarta & 9.607 .787 & $34 \%$ & 137 \\
Bogor & 5.722 .266 & $20 \%$ & 82 \\
Depok & 1.738 .570 & $6 \%$ & 25 \\
Tangerang & 5.923 .299 & $21 \%$ & 85 \\
Bekasi & 4.965 .272 & $18 \%$ & 71 \\
Total & 27.957 .194 & $100 \%$ & 400 \\
\hline
\end{tabular}

Sumber :BPS (16)

\section{HASIL DAN PEMBAHASAN}

Berdasarkan hasil uji validitas terlihat total skor kontruk dari setiap variabel menunjukan hasil yang signifikan, dan menunjukan bahwa nilai $\mathrm{r}_{\text {hitung }}>$ dari $r_{\text {tabel }}$ yang menyatakan bahwa item pertanyaan tersebut dinyatakan valid. Sedangkan hasil uji reliabelitas menunjukan semua variabel mempunyai koefisien a yang cukup besar yaitu diatas 0,60, sehingga dapat dikatakan semua konsep pengukur masing-masing variabel dari kuisioner adalah reliabel sehingga untuk selanjutnya item-item pada masing-masing konsep variabel tersebut layak digunkaan sebagai alat ukur.

\section{Karakteristik Responden}

Karakteristik responden pada penelitian ini didasarkan pada jenis kelamin, usia, pendidikan dan pekerjaan yang ditekuni. Karekteristik usia responden diambil dari usia 16 tahun hingga $>65$ tahun. Kemudian responden juga dilihat berdasarkan tingkat pendidikan terakhir dan jenis pekerjaan yang diemban pada saat mengisi kuisioner.
Tabel 2. Karakteristik Responden

\begin{tabular}{|c|c|c|}
\hline Karakteristik Responden & $\mathbf{n}$ & $\%$ \\
\hline \multicolumn{3}{|l|}{ Jenis Kelamin } \\
\hline Pria & 176 & $44 \%$ \\
\hline Wanita & 224 & $56 \%$ \\
\hline \multicolumn{3}{|l|}{ Usia (Tahun) } \\
\hline $16-20$ & 33 & $8 \%$ \\
\hline $21-30$ & 187 & $47 \%$ \\
\hline $31-40$ & 101 & $25 \%$ \\
\hline $41-50$ & 43 & $11 \%$ \\
\hline $51-60$ & 20 & $5 \%$ \\
\hline$>60$ & 16 & $4 \%$ \\
\hline \multicolumn{3}{|l|}{ Pendidikan Terakhir } \\
\hline SD & & $0 \%$ \\
\hline SMP & & $0 \%$ \\
\hline SMA/ SMK & 150 & $38 \%$ \\
\hline Diploma & 24 & $6 \%$ \\
\hline Sarjana (S1) & 162 & $41 \%$ \\
\hline Pasca Sarjana (S2/S3) & 64 & $16 \%$ \\
\hline \multicolumn{3}{|l|}{ Pekerjaan } \\
\hline Guru/Dosen & 15 & $4 \%$ \\
\hline Karyawan Swasta & 221 & $55 \%$ \\
\hline Karyawan BUMN & 38 & $10 \%$ \\
\hline ASN & 15 & $4 \%$ \\
\hline Wiraswasta & 48 & $12 \%$ \\
\hline Pelajar/Mahasiswa & 43 & $11 \%$ \\
\hline Pensiunan/Tidak berkerja & 20 & $5 \%$ \\
\hline
\end{tabular}

Sumber: data primer yang telah diolah

Karakteristik responden berdasarkan jenis kelamin didapat bahwa wanita akan lebih memperhatikan masalah kesahatan dibandingkan dengan pria (20). Sedangkan berdasarkan usia responden didapat bahwa 187 responden (47\%) pada usia 21-30 tahun. Responden pada usia produktif akan cenderung merespon dan mengikuti perkembangan ilmu pengetahuan (21).

Berdasarkan data pada tabel 2 didapat jumlah responden tertinggi terdapat pada jenjang sarjana $(41 \%)$ dan SMA/SMK (38\%). Pendidikan diaharapkan mampu untuk meningkatkan kepatuhan masyarakat dalam mentaati peraturan yang telah diterapkan (22). Berdasarkan karakteristik pekerjaan responden didapat bahwa 
$55 \%$ responden merupakan karyawan swasta yang memiliki tanggung jawab pada pekerjaannya (23). Selain itu, pekerjaan yang dimiliki tidak akan mempengaruhi seseorang agar patuh terhadap suatu kebijakan (24). Sehingga semua akan kembali kepada kesadaran masing-masing dalam menanggapi suatu kebijakan.

\section{Analisis Jalur Model 1}

Pengujian analisis jalur model 1 dilakukan untuk mengetahui pengaruh langsung variabel pendidikan dan pekerjaan terhadap pengetahuan mengenai COVID-19. Berdasarkan hasil perhitungan nilai koefisien didapat nilai beta variabel pendidikan $=0,166$ dan variabel pekerjaan $=0,092$. Selanjutnya didapat hasil perhitungan nilai uji $\mathrm{t}$ pada variabel pendidikan $=3,316$ dan variabel pekerjaan $=1,842$.

Tabel 3. Hasil Perhitungan Koefisien Analisis Jalur Model 1

\begin{tabular}{lccc}
\hline Variabel & $\begin{array}{c}\text { Standardized } \\
\text { Coefficients }\end{array}$ & $\mathbf{t}$ & Sig. \\
\cline { 1 - 2 } Beta & & \\
\hline (Constant) & & 32,201 & 0,000 \\
Pendidikan & 0,166 & 3,316 & 0,001 \\
Pekerjaan & 0,092 & 1,842 & 0,066 \\
\hline
\end{tabular}

Sumber: hasil pengolahan SPSS 21

Berdasarkan tabel 3, didapat nilai signifikansi pendidikan sebesar 0,001 atau lebih kecil dari 0,05. Sehingga dapat disimpulkan bahwa secara langsung terdapat pengaruh signifikan pendidikan terhadap pengetahuan mengenai Covid-19. Sementara, nilai signifikansi pekerjaan sebesar 0,066 atau lebih besar dari 0,05. Sehingga dapat disimpulkan bahwa secara langsung tidak terdapat pengaruh signifikan pekerjaan terhadap pengetahuan mengenai Covid-19. Senada dengan Wirantika bahwa pendidikan akan mampu meningkatkan pengetahuan seseorang terhadap suatu penyakit (25). Pendidikan juga dapat meningkatkan daya tangkap sesorang dalam meyerap informasi dengan objektif (26). Secara psikologis pengetahuan seorang pekerja akan sangat dipengaruhi oleh lingkungan tempatnya berkerja (27). Sehingga seseorang akan cenderung untuk belajar dengan cepat berdasarkan kondisi yang terjadi pada lingkungan pekerjaan mereka.

Tabel 4. Nilai R dan R² Analisis Jalur Model 1

\begin{tabular}{ccccc}
\hline Model & $\mathbf{R}$ & $\begin{array}{c}\mathbf{R} \\
\text { Square }\end{array}$ & $\begin{array}{c}\text { Adjusted } \\
\text { R Square }\end{array}$ & $\begin{array}{c}\text { Std. Error } \\
\text { of the } \\
\text { Estimate }\end{array}$ \\
\hline 1 & 0,204 & 0,042 & 0,037 & 7,34577 \\
\hline
\end{tabular}

Sumber: hasil pengolahan SPSS 21

Hasil perhitungan $\mathrm{R}^{2}$ pada tabel 4 didapat nilai $\mathrm{R}^{2}=0,042$, menandakan bahwa pendidikan dan pekerjaan mempunyai pengaruh sebesar 4,2\% terhadap pengetahuan dan sisanya sebesar 95,8\% dipengaruhi variabel lainya yang tidak dimasukan dalam penelitian. Selanjutnya pada tabel 1 didapat nilai signifikansi variabel pendidikan $=0,001$ lebih kecil dari 0,05 sedangkan nilai signifikansi variabel pekerjaan $=0,066$ lebih besar dari 0,05. Hasil ini menunjukan bahwa padal analisis jalur model 1 hanya variabel pendidikan yang memiliki pengaruh signifikan terhadap pengetahuan. Sehingga dapat disusun diagram analisis jalur model 1 dengan $\mathrm{e}_{1}=$ $\sqrt{ }(1-0,042)=0,979$.

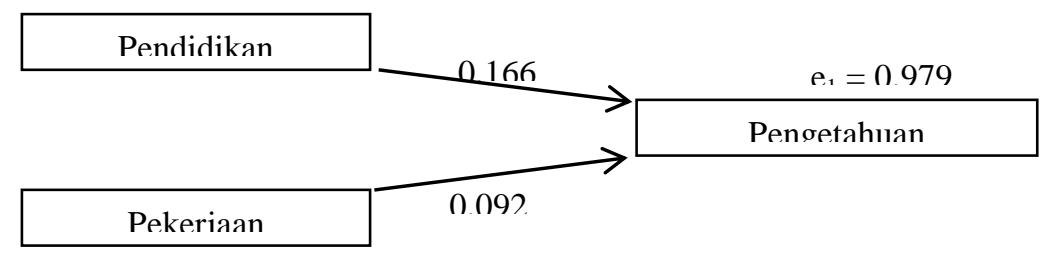

Gambar 1. Diagram Analisis Jalur Model 1

\section{Analisis Jalur Model 2}

Pengujian analisis jalur model 2 dilakukan untuk mengetahui pengaruh langsung variabel pendidikan dan pekerjaan terhadap pengetahuan mengenai COVID-19. Berdasarkan hasil perhitungan nilai koefisien didapat nilai beta variabel pendidikan $=0,066$, variabel pekerjaan $=$ 0,016 , dan variabel pengetahuan $=0,556$. 
Selanjutnya didapat hasil perhitungan nilai uji $\mathrm{t}$ pada variabel pendidikan $=1,555$, variabel pekerjaan $=-0,391$ dan variabel pengetahuan $=$ 13,181 .

Tabel 5. Hasil Perhitungan Koefisien Analisis Jalur Model 2

\begin{tabular}{lccc}
\hline \multirow{2}{*}{ Variabel } & $\begin{array}{c}\text { Standardized } \\
\text { Coefficients }\end{array}$ & $\mathbf{t}$ & Sig. \\
\cline { 2 - 2 } & Beta & & \\
\hline (Constant) & & 4,809 & 0,000 \\
Pendidikan & 0,066 & 1,555 & 0,121 \\
Pekerjaan & $-0,016$ & $-0,391$ & 0,696 \\
Pengetahuan & 0,556 & 13,181 & 0,000 \\
\hline
\end{tabular}

Sumber: hasil pengolahan SPSS 21

\section{Pengaruh Langsung}

Berdasarkan tabel 5, didapat nilai signifikansi pendidikan sebesar 0,121 atau lebih besar dari 0,05. Sehingga dapat disimpulkan bahwa secara langsung tidak terdapat pengaruh signifikan pendidikan terhadap Kepatuhan penerapan PSBB. Sementara, didapat nilai signifikansi pekerjaan sebesar 0,696 atau lebih besar dari 0,05. Sehingga dapat disimpulkan bahwa secara langsung tidak terdapat pengaruh signifikan pekerjaan terhadap Kepatuhan penerapan PSBB.

Hasil perhitungan pada tabel 5 menunjukan nilai signifikansi pengetahuan sebesar 0,000 atau lebih kecil dari 0,05. Sehingga dapat disimpulkan bahwa secara langsung terdapat pengaruh signifikan pengetahuan terhadap Kepatuhan penerapan PSBB. Hal ini menunjukan bahwa pengetahuan merupakan factor yang akan mempengaruhi kepatuhan seseorang (28).

\section{Pengaruh Tidak Langsung}

Pada tabel 5 diketahui terdapat pengaruh langsung yang diberikan pendidikan terhadap kepatuhan sebesar 0,066. Sedangkan pengaruh tidak langsung pendidikan melalui pengetahuan terhadap kepatuhan adalah perkalian antara nilai pendidikan terhadap pengetahuan dengan nilai pengetahuan terhadap kepatuhan yaitu 0,166 $\mathrm{x}$ $0,566=0,094$. Maka pengaruh total yang diberikan pendidikan terhadap kepatuhan adalah pengaruh langsung ditambah pengaruh tidak langsung yaitu $0,066+0,094=0,160$.
Berdasarkan hasil perhitungan diketahui bahwa nilai pengaruh tidak langsung $(0,094)$ lebih besar dibandingkan nilai pengaruh langsung $(0,066)$, hasil ini menunjukan bahwa secara tidak langsung pendidikan melalui pengetahuan mempunyai pengaruh signifikan terhadap kepatuhan. Kepatuhan dapat membentuk perilaku manusia yang taat pada aturan dan prosedur yang ditetapkan, serta disiplin dalam menjalankanya (29). Namun, bila dihubungkan dengan pengobatan kepatuhan merupakan ketaatan pada petunjuk pengobatan, diikuti dengan perubahan gaya hidup dan melaksanakan masukan dari tenaga kesehatan (30).

Diketahui terdapat pengaruh langsung yang diberikan pekerjaan terhadap kepatuhan sebesar 0,016. Sedangkan pengaruh tidak langsung pekerjaan melalui pengetahuan terhadap kepatuhan adalah perkalian antara nilai pekerjaan terhadap pengetahuan dengan nilai pengetahuan terhadap kepatuhan yaitu - 0,016 x 0,566 = -0,009. Maka pengaruh total yang diberikan pekerjaan terhadap kepatuhan adalah pengaruh langsung ditambah pengaruh tidak langsung yaitu - 0,016 + $0,009=-0,025$.

Berdasarkan hasil perhitungan diketahui bahwa nilai pengaruh tidak langsung $(-0,009)$ lebih besar dibandingkan nilai pengaruh langsung (0,016), hasil ini menunjukan bahwa secara tidak langsung pekerjaan melalui pengetahuan mempunyai pengaruh signifikan terhadap kepatuhan. Semua pekerjaan pasti memiliki tanggung jawab yang diemban (23). Sehingga ketidakpatuhan terjadi bukan karena kurangnya pengetahuan namun terjadi karena tanggung jawab akibat banyak responden berkerja pada bidang pekerjaan yang tetap diizinkan beroperasi oleh Pemerintah seperti rumah sakit, pedagang atau retiler kebutuhan sehari-hari dan lainnya.

Tabel 6. Nilai R dan R² Analisis Jalur Model 2

\begin{tabular}{ccccc}
\hline Model & $\mathbf{R}$ & $\begin{array}{c}\mathbf{R} \\
\text { Square }\end{array}$ & $\begin{array}{c}\text { Adjusted } \\
\text { R Square }\end{array}$ & $\begin{array}{c}\text { Std. Error } \\
\text { of the } \\
\text { Estimate }\end{array}$ \\
\hline 2 & $\begin{array}{c}0,57 \\
0\end{array}$ & 0,325 & 0,320 & 4,72218 \\
\hline
\end{tabular}

Sumber: hasil pengolahan SPSS 21 
Pada hasil perhitungan tabel 6 didapat nilai $\mathrm{R}$ Square $=0,325$, hal ini menandakan bahwa pendidikan, dan pekerjaan melalui pengetahuan mempunyai pengaruh sebesar $32,5 \%$ terhadap kepatuhan dan sisanya sebesar $67,5 \%$ dipengaruhi variabel lainya yang tidak dimasukan dalam penelitian. Kemudian pada tabel 3 didapat nilai signifikansi dari variabel pendidikan $=0,121$, pekerjaan $=0,696$ lebih besar dari 0,05 sementara nilai signifikansi variabel pengetahuan $=0,000$ lebih kecil dari 0,05. Dapat ditarik kesimpulan bahwa pada analisis jalur model 2 variabel kepatuhan dipengaruhi secara signifikan oleh variabel pengetahuan sedangkan variabel pendidikan dan pekerjaan tidak berpengaruh signifikan terhadap kepatuhan. Sehingga dapat disusun diagram analisis jalur model 2 dengan $\mathrm{e}_{2}=\sqrt{ }(1-0,325)=0,822$.

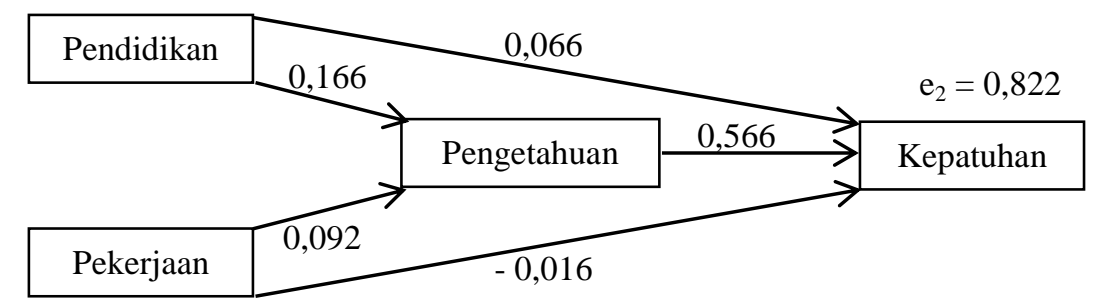

Gambar 2. Diagram Analisis Jalur Model 2

\section{KESIMPULAN DAN SARAN}

Pendidikan memiliki pengaruh signifikan secara tidak langsung melalui pengetahuan terhadap kepatuhan penerapan PSBB sebesar 0,094. Sementara pekerjaan memiliki pengaruh signifikan secara tidak langsung melalui pengetahuan terhadap kepatuhan penerapan PSBB sebesar 0,009 . Sedangakan, pengetahuan mengenai COVID19 mempunyai pengaruh langsung sebesar 0,566 terhadap kepatuhan penerapan PSBB. Pengaruh pendidikan dan pekerjaan melalui pengetahuan terhadap kepatuhan hanya sebesar 32,5\%, sehingga disarankan bagi peneliti selanjutnya mencari variabel lain yang mampu mempengaruhi kepatuhan sehingga penyebaran COVID-19 dapat segera ditekan.

\section{DAFTAR PUSTAKA}

1. Sheposh R. 'Coronavirus 2019 (COVID-19).' Salem Press Encyclopedia of Health [Internet]. 2020 May 17; Available from: http://e-

resources.perpusnas.go.id:2077/login.aspx? direct $=$ true $\& \mathrm{db}=$ ers $\& A N=142379071 \&$ site $=e$ ds-live

2. Yang W, Cao Q, Qin L, Wang X, Cheng Z, Pan A, et al. Clinical characteristics and imaging manifestations of the 2019 novel coronavirus disease (COVID-19):A multicenter study in Wenzhou city, Zhejiang, China. J Infect [Internet]. 2020 Apr;80(4):388-93. Available from: https://linkinghub.elsevier.com/retrieve/p ii/S0163445320300992

3. Xu Z, Shi L, Wang Y, Zhang J, Huang L, Zhang $C$, et al. Pathological findings of COVID-19 associated with acute respiratory distress syndrome. Lancet Respir Med [Internet]. 2020;2600(20):19-21. Available from: http://dx.doi.org/10.1016/S22132600(20)30076-X

4. WHO. Coronavirus [Internet]. www.who.int. 2020. Available from: https://www.who.int/healthtopics/coronavirus\#tab=tab_1

5. Yanping Z. The Epidemiological Characteristic of an outbreak of 2019 Novel Coronavirus Diseases (COVID-19). Chin J Epidemiol. 2020;41(2):145-51.

6. worldmeters.info. Covid-19 Corona Virus Pandemeic [Internet]. www.worldmeters.info. 2020 [cited 2020 Mar 25]. Available from: https://www.worldometers.info/coronavir us

7. Covid19.go.id. Situasi Virus Corona [Internet]. www.Covid19.go.id. 2020 [cited 2020 May 17]. Available from: https://www.covid19.go.id/situasi-virus- 
8. Yunita NW. Penyebab, Asal Mula, dan Pencegahan Virus Corona di Indonesia. www.detik.com [Internet]. 2020 Mar 28; Available from: https:/ / news.detik.com/berita/d4956764/penyebab-asal-mula-danpencegahan-virus-corona-di-indonesia

9. Peraturan Gubernur DKI. Peraturan Gubernur Provinsi Daerah Khusus Ibukota Jakarta Nomor 33 Tahun 2020 Tentang Pelaksanaan Pemabtasan Sosial Berskala Besar. 2020.

10. Kemenkes RI. Peraturan Menteri Kesehatan Republik Indonesia Nomor 9 Tahun 2020 Tentang Pedoman Pembatasan Sosial Berskala Besar Dalam Rangka Percepatan Penanganan Corona Virus Disease 2019 (Covid-19). 2020;13. Available from: http://hukor.kemkes.go.id/uploads/produ k_hukum/PMK_No_9_Th_2020_ttg_Pedo man_Pembatasan_Sosial_Berskala_Besar_D alam_Penanganan_COVID-19.pdf

11. Nasruddin R, Haq I. Pembatasan Sosial Berskala Besar (PSBB) dan Masyarakat Berpenghasilan Rendah. SALAM J Sos dan Budaya Syar-i [Internet]. 2020 May 25;7(7). Available from: http:/ /journal.uinjkt.ac.id/index.php/sala $\mathrm{m} /$ article/view/15569

12. Puji S. Duduk Perkara 15 Warga Sidoarjo Positif Covid-19, Berawal Nekat Buka Plastik dan Memandikan Jenazah Pasien Corona. Kompas.com [Internet]. 2020; Available from: https://regional.kompas.com/read/2020/0 5/18/08352271/duduk-perkara-15-wargasidoarjo-positif-covid-19-berawal-nekatbuka-plastik

13. Sugiyono. Statistika untuk Penelitian. 27th ed. Bandung: Alfabeta; 2016.

14. Arikunto S. Prosedur Penelitian. Jakarta: Rineka Cipta; 2010.

15. Notoatmodjo S. Metodelogi Penelitian Kesehatan. Jakarta: Rineka Cipta; 2010.

16. BPS.go.id. Pencarian Data [Internet]. https://sp2010.bps.go.id. 2010. Available from:

https://sp2010.bps.go.id/index.php/naviga tion/datafinder

17. Putri BS, Kartika L. Pengaruh Kualitas Pelayanan Bpjs Kesehatan Terhadap Kepuasan Pengguna Perspektif Dokter Rumah Sakit Hermina Bogor. J Ris Manaj dan Bisnis Fak Ekon UNIAT [Internet]. 2017 Apr 15;2(1):1-12. Available from: http://jrmb.ejournal-

feuniat.net/index.php/JRMB/article/view/ 24

18. Haryono N, Octavia R. Analisis Pengaruh Citra Merek Dan Mutu Layanan Terhadap Kepuasan Konsumen Serta Dampaknya Terhadap Loyalitas Konsumen. J Ind Elektro dan Penerbangan. 2020;4(1):20-7.

19. Handayani LT. Analisis Jalur Keselamatan Dan Kesehatan Kerja Dengan Kepuasan Terhadap Kinerja Perawat Dalam Memberikan Asuhan Keperawatan Di Rs Di Jember. Indones J Heal Sci. 2017;9(1):43-54.

20. Ekadipta E, Andri Arthono. Analisis Prefensi Konsumen Jamu Dalam Kemasan Di Wilayah Jabodetabek. In: Prosiding Seminar Nasional Hasil Penelitian dan Pengabdian Masyarakat "Kesehatan Modern dan Tradisional" - Diseminasi Penelitian [Internet]. Yogyakarta: DPPM (Direktorat Penelitian dan Pengabdian Masyarakat) UII; 2020. p. 96-111. Available from:

https://dspace.uii.ac.id/handle/123456789 /25889

21. Pratiwi H, Nury7anti N, Fera VV, Warsinah W, Sholihat NK. Pengaruh edukasi terhadap pengetahuan, sikap, dan kemampuan berkomunikasi atas informasi obat. Kartika J Ilm Farm [Internet]. 2016 Jun 6;4(1). Available from: http://kjif.unjani.ac.id/index.php/kjif/artic le/view/51

22. Putri LR. Pengaruh Motivasi Membayar Pajak Dan Tingkat Pendidikan Terhadap Kepatuhan Wajib Pajak Orang Pribadi. J profita Ed 8 tahun 2016. 2016;8(2):1-12.

23. Udin KA. Hubungan antara tingkat pendidikan dan jenis pekerjaan dengan partisipasi masyarakat dalam pembangunan di Desa Jetis Kecamatan Jaten Kabupaten Karanganyar tahun 2009/2010. Univ Sebel Maret. 2010;

24. Amilin A, Yusronillah F. Analisis Pengaruh Tingkat Pendidikan Dan Jenis Pekerjaan Wajib Pajak Terhadap Motivasi Dalam Memenuhi Kewajiban Pajak. J Manaj dan Keuang Darmajaya. 2009;7(3):28-43.

25. Wahyu Ratna WYS. Pengaruh Pendidikan Kesehatan terhadap Pengetahuan dan Perilaku Siswa dengan Persebaran Demam Berdarah Dengue (DBD) Di Sekolah. J Heal [Internet]. 2020;1(6):427-31. Available from: http://jurnal.healthsains.co.id/index.php/j hs/article/view/62

26. Ekadipta E, Muhammad Sadikin, 


\footnotetext{
Muhammad Rizqi Yusuf. Kualitas

Pemberian Informasi Obat pada Pelayanan Resep Berdasarkan Kepuasan Pasien BPJS Puskesmas Kecamatan Cilandak. Pharm J Farm Indones (Pharmaceutical J Indones [Internet]. 2019 Dec 31;16(2):244. Available from:

http://jurnalnasional.ump.ac.id/index.php /PHARMACY/article/view/4920

27. Fitriyani, Dewi, Eko Prasetyo, Reni Yustien Ah. Pengaruh gender, latar belakang pekerjaan, dan tingkat pendidikan terhadap kepatuhan wajib pajak. InFestasi. 2014;10(2):115-24.

28. Rusida ERR adhani; RP. Pengaruh Tingkat Pengetahuan, Motivasi dan Faktor Obat Terhadap Kepatuhan Minum Obat Pasien Hipertensi di Puskesmas Kota Banjarbaru Tahun 2017. J Pharmascience. 2017;4(2):13041.

29. Ivoryanto E, Sidharta B, Illahi RK. Hubungan Tingkat Pendidikan Formal Masyarakat terhadap Pengetahuan dalam Penggunaan Antibiotika Oral di Apotek Kecamatan Klojen. Pharm J Indones. 2017;2(2):31-6.

30. Sari ID, Mubasyiroh R, Supardi S. Hubungan Pengetahuan dan Sikap dengan Kepatuhan Berobat pada Pasien TB Paru yang Rawat Jalan di Jakarta Tahun 2014. Media Penelit dan Pengemb Kesehat. 2017;26(4):243-8.
} 